\section{TINJAUAN YURIDIS PEMBENTUKAN PERATURAN PRESIDEN (PERPRES) NOMOR 64 TAHUN 2020 TENTANG PERUBAHAN KEDUA ATAS PERATURAN PRESIDEN (PERPRES) NOMOR 82 TAHUN 2018 TENTANG JAMINAN KESEHATAN TERKAIT KENAIKAN IURAN BPJS PASCA PUTUSAN MAHKAMAH AGUNG (MA) NOMOR 7P/HUM $/ 2020^{1}$ \\ Oleh : Devid Winowod ${ }^{2}$ \\ Theodorus H. W. Lumunon ${ }^{3}$ Nelly Pinangkaan ${ }^{4}$}

\section{ABSTRAK}

Tujuan dilakukannya penelitian ini adalah untuk mengetahui bagaimana pelayanan terhadap pasien yang menggunakan fasilitas BPJS di Provinsi Sulawesi Utara dan bagaimana sikap pemerintah Provinsi Sulawesi Utara dengan kondisi naik turunnya tarif BPJS. Dengan menggunakan metode peneltian yuridis normatif, disimpulkan: 1. Dari hasil penelitian yang diperoleh, maka dapat disipulkan bahwa persepsi keluarga pasien pengguna layanan BPJS kesehatan terhadap pelayanan di Rumah Sakit Islam Kendal baik yang dilihat dari segi prosedur pelayanan admisitrasi, kualitas pelayanan rawat inap, maupun sarana dan prasarana termasuk dalam kategori baik. Hal itu bisa dilihat dari besarnya skor persepsi baik terhadap pelayanan Rumah sakit Islam Kendal, yaitu sebanyak 63,6\%, Yang artinya sebagian besar keluarga pasien pengguna layanan kesehatan BPJS mempunyai persepsi yang baik terhadap kualitas pelayanan BPJS di Rumah Sakit Islam Kendal. 2. Dalam hal ini, satusatunya solusi yang bisa Penulis kemukakan bagi pemerintah dan pihak-pihak terkait ialah dengan mencari akar primordial dari problem yang ada. Perlu adanya observasi mendalam dan tinjauan yang berlanjut untuk mendapatkan kepastian akan perihal yang melatarbelakangi defisit keuangan menahun yang dialami oleh BPJS Kesehatan tersebut. Sebab tidak menutup kemungkinan akan adanya kausa-kausa lain yang menyebabkan problem itu terjadi, dan karenanya akan

\footnotetext{
${ }^{1}$ Artikel Skripsi

2 Mahasiswa pada Fakultas Hukum Unsrat, NIM. 13071101428

${ }^{3}$ Fakultas Hukum Unsrat, Doktor IImu Hukum

${ }^{4}$ Fakultas Hukum Unsrat, Magister IImu Hukum
}

tercipta suatu jalan tengah yang menguntungkan bagi kita semua

Kata kunci: Tinjauan Yuridis, Pembentukan Peraturan Presiden, Jaminan Kesehatan Putusan Mahkamah Agung

\section{PENDAHULUAN}

\section{A. Latar Belakang}

Pembangunan kesehatan bagi pemerintah pusat maupun daerah harus saling bahu membahu dalam melaksanakan pembangunan kesehatan yang terencana dan terpadu dalam upaya mewujudkan derajat kesehatan yang setinggi-tingginya. Salah satu instansi yang menyelenggrakan pelayanan kesehatan adalah rumah sakit. Rumah sakit sesuai dengan fungsinya (melaksanakan pelayanan medis, dan pelayanan penunjang medis) berkewajiban mengupayakan, menyediakan, dan menyelenggarakan pelayanan bermutu dan memenuhi kebutuhan masyarakat akan pelayanan yang berkulitas. Dalam undangundang 1945 pasal 28 ayat 1 yang menggariskan bahwa setiap rakyat berhak atas pelayanan kesehatan yang setinggi-tingginya tanpa membedakan suku, golongan, agama, jenis kelamin, dan status sosial, ekonomi. Namum pada kenyataanya pelayanan yang diberikan oleh beberapa instansi penyedia pelayanan termasuk rumah sakit masih belum sesuai dengan apa yang digariskan oleh undang-undang, salah satunya adalah adanya diskriminasi yang didapatkan masyarakat dalam hal pelayanan kesehatan.

Sebagaimana dalam undang-undang RI Nomor 44 Tahun 2009 tentang pengaturan penyelenggraan rumah sakit di tegaskan dalam pasal 3 yang bertujuan untuk mempermudah akses masyarakat untuk mendapatkan pelayanan kesehatan, memberikan perlindungan terhadap keselamatan pasien, masyarakat, lingkungan rumah sakit dan sumber daya manusia di rumah sakit. meningkatkan mutu dan standar pelayanan rumah sakit. memberikan kepastian hukum kepada pasien, masyarakat, sumber daya manusia di rumah sakit. Namun pada kenyataanya masih ada rumah sakit yang memberikan pelayanan yang berbelit-belit, tidak professional serta lamban dalam melayani pasien. 
Pada 1 Juli 2020, pemerintah secara resmi memberlakukan kebijakan kenaikan tarif iuran BPJS Kesehatan yang berdasar pada Peraturan Presiden Nomor 64 Tahun 2020. Perpres ini sendiri berisikan perubahan kedua atas Peraturan Presiden Nomor 82 Tahun 2018 tentang Jaminan Kesehatan. Secara spesifik, di dalam Perpres tersebut, diatur mengenai kenaikan tarif iuran untuk para peserta program JKN BPJS Kesehatan yang terbagi ke dalam tiga segmentasi.

Pemerintah pusat berargumen bahwa kebijakan kenaikan tarif iuran ini dipandang perlu, demi memperbaiki tata kelola asuransi kesehatan bagi rakyat secara keseluruhan. Namun nyatanya, alih-alih disambut, masyarakat justru dibuat kalut. Kebijakan tersebut menuai kritik keras dari berbagai pihak. Belum lagi adanya sikap dari lembaga negara terkait yang seolah tidak pro rakyat dan cenderung tertutup

\section{B. Rumusan Masalah}

1. Bagaimana pelayanan terhadap pasien yang menggunakan fasilitas BPJS di Provinsi Sulawesi Utara?

2. Bagaimana sikap pemerintah Provinsi Sulawesi Utara dengan kondisi naik turunnya tarif BPJS?

\section{Metode Penelitian}

Penelitian yang digunakan dalam penulisan skripsi ini adalah penelitian deskriptif sebagai salah satu bentuk penelitian hukum normatif, adapun bentuk penelitian hukum normatif adalah penelitian dengan hanya mengolah dan menggunakan data-data sekunder yang berkaitan dengan Hukum Tata Negara.

\section{PEMBAHASAN}

\section{A. Gambaran Umum Penelitian}

Makna pendidikan menurut Dictionary of Education (2004) 5adalah suatu proses di mana seseorang mengembangkan kemampuan, sikap dan bentuk tingkah laku lainnya di dalam lingkungan masyarakat. Pendidikan dapat diartikan sebagai suatu proses atau kegiatan untuk mengembangkan kepribadian dan kemampuan individu atau masyarakat. Ini berarti bahwa pendidikan adalah suatu pembentukan watak yaitu sikap disertai

${ }^{5}$ Dictionary Of Education (2004) kemampuan dalam bentuk kecerdasan, pengetahuan dan ketrampilan.

Pekerjaan adalah sesuatu yang dikerjakan untuk mendapatkan nafkah atau pencaharian. Dengan adanya pekerjaan seseorang akan memerlukan banyak waktu dan perhatian. Orang yang sibuk hanya memiliki sedikit waktu untuk memperoleh informasi, sehingga pengetahuan yang mereka peroleh kemungkinan juga berkurang (Notoatmojo, 2005) $)^{6}$.

1. Penilaian persepsi keluarga tentang prosedur pelayanan diantaranya meliputi prosedur pendaftaran, persyaratan pendaftaran BPJS, sikap petugas pelayanan administrasi, kejelasan informasi dari petugas tentang fasilitas yang di peroleh pasien BPJS, serta waktu tunggu untuk mendapatkan pelayanan. $\mathrm{Hal}$ ini sesuai dengan Purnama (2000:20) ${ }^{7}$ yang menyatakan kualitas pelayanan meliputi:

- Kualitas fungsi yang menekankan bagaimana pelayanan dilakukan, terdiri dari dimensi kontak dengan pasien, sikap dan perilaku, hubungan internal, penampilan, kemudahan akses, dan servis.

- Kualitas teknis dengan kualitas output yang dirasakan konsumen, meliputi harga, ketepatan waktu, kecepatan layanan dan estetika output.

- Reputasi perusahaan yang dicerminkan oleh citra perusahaan dan reputasi di mata konsumen.

Hasil penelitian pada prosedur pelayanan administrasi pada BPJS dikategorikan baik, hal ini dikarenakan prosedur di Rumah Sakit Islam mudah dan tidak berbelit-belit, apabila terdapat kekurangan persyaratan petugas selalu memberitahu kekurangannya, tidak membedabedakan status pasien serta memberi informasi dengan jelas dan mudah di mengerti.

2. Penilaian persepsi keluarga tentang kualitas pelayanan rawat inap meliputi

\footnotetext{
${ }^{6}$ (Notoatmojo, 2005)

7 Purnama (2000:20)
} 
kejelasan informasi dari petugas, prosedur untuk rawat inap, fasilitas bagi BPJS, pelayanan yang tidak membedakan, pelayanan yang sesuai dengan kebutuhan dan diagnosa pasien, keramahan dan kesopanan pasien serta komunikasi yang baik dari petugas apabila melakukan tindakan. Hal ini sesuai dengan lima dimensi kualitas pelayanan menurut Parasuraman dalam lupiyodi (2006:182) ${ }^{8}$ yaitu: Tangibles atau bukti fisik, Reliability atau kehandalan rumah sakit dalm memberikan pelayanan yang dijanjikan secara akurat dan terpercaya, Responsivenes atau kemauan petugas dalam dalam membantu dan memberikan pelayanan yang cepat dan tepat serta penyampaian informasi yang jelas, Assurance atau yang meliputi beberapa komponen antara lain komunikasi, kredibilitas, keamanan, kompetensi dan sopan santun, serta Empathy yaitu perhatian yang tulus dan bersifat individual yang diberikan kepada pasien dengan berupaya memahami kebutuhan pasien. Kualitas pelayanan rawat inap dikategorikan baik karena petugas memberikan informasi dengan jelas, pasien dilayani sesuai dengan kebutuhan dan diagnosanya, petugas yang ramah dan sopan serta setiap memberikan tindakan selalu dengan persetujuan pasien dan keluarga.

3. Sarana dan prasarana yang di nilai disini meliputi kerapihan tempat tidur dan ruangan serta kebersihan kamar mandi, fasilitas perawatan, kelengkapan obat-obatan, serta penggunaan fasilitas dan alat kesehatan. Hal ini sesuai dengan point pertama dari lima dimensi. kualitas pelayanan yang di kemukakan parasuraman dalam Lupiyoadi (2006:182) ${ }^{9}$ yaitu Tangibles atau bukti fisik, yaitu kemampuan rumah sakit atau perusahaan dalam menunjukkan eksistensinya kepada pihak eksternal.
Penampilan serta kemampuan sarana dan prasarana fisik rumah sakit dan keadaan lingkungan sekitarnya adalah bukti nyata dari pelayanan yang diberikan. Persepsi terhadap sarana dan prasarana BPJS di RSI Kendal dikategorikan baik, terbukti dari banyaknya responden yang setuju dengan kebersihan dan kerapian tempat tidur serta kamar mandi yang bersih, fasilitas rumah sakit yang lengkap, obat-obatan yang lengkap dan selalu tersedia, dan pasien dapat menggunakan fasilitas yang tersedia seperti Rongent, USG, operasi serta tranfusi darah.

Persepsi tidak baik sebanyak 20 responden $(36,4 \%)$, hal itu dikarenakan ada sebagian kecil dari responden merasa kurang puas terhadap beberapa item penilaian persepsi pasien, misalnya dalam prosedur pelayanan administrasi responden merasa kurang puas karena baru pertama dirawat dengan menggunakan BPJS sehingga kurang paham dengan prosedur yang harus dilakukan, serta kurang nyaman dengan ruangan yang ramai.

\section{B. Sikap pemerintah Terkait kenaikan luran BPJS Pasca Putusan Mahkamah Agung (MA) Nomor 7P/HUM/2020}

1. Kebijakan Baru

Semua bermula dari tahun 2018. Saat itu, presiden menandatangani Peraturan Presiden Nomor 82 Tahun 2018 yang mengatur mengenai Jaminan Kesehatan (Perpres Jaminan Kesehatan). ${ }^{10}$ Melalui peraturan ini, pemerintah mengupayakan untuk membenahi penyelenggaraan dari program Jaminan Kesehatan Nasional (JKN) agar sepenuhnya bermanfaat bagi seluruh masyarakat. Perpres Jaminan Kesehatan tersebut juga merupakan beleid yang menggantikan Peraturan Presiden Nomor 12 Tahun 2013 yang telah banyak mengalami perubahan, dan yang terakhir melalui Peraturan Presiden Nomor 28 Tahun 
$2016^{11}$ yang mengatur masalah serupa. Penulis berpendapat bahwa alasan pengadaan dan pemberlakuan regulasi terkait program JKN BPJS Kesehatan tidak lain merupakan manifestasi dari cita-cita bangsa Indonesia. la ada sebagai pemenuhan salah satu anasir kesejahteraan umum yang memang sepantasnya diwujudkan. Sebagaimana tercantum di dalam Alinea ke-2 UUD NRI Tahun $1945^{12}$ yang berbunyi sebagai berikut: "Dan perjuangan pergerakan kemerdekaan Indonesia telah sampailah kepada saat yang berbahagia dengan selamat sentosa mengantarkan rakyat Indonesia ke depan pintu gerbang kemerdekaan negara Indonesia, yang merdeka, bersatu, berdaulat, adil dan makmur."

2. Teatrikal Lembaga-lembaga Negara Semenjak diberlakukan mulai dari 1 Januari 2020, Perpres Jaminan Kesehatan Perubahan Pertama, sontak menuai protes di tengah-tengah masyarakat. Tidak tanggung-tanggung, berbagai kalangan baik akademisi maupun masyarakat awam, ikut menyuarakan aspirasi mereka atas kenaikan tarif iuran BPJS yang naik sebanyak seratus persen untuk kalangan PBPU-BP (Pekerja Bukan Penerima Upah dan Bukan Pekerja) dalam Perpres tersebut. Bahkan, DPR mengecam adanya pemberlakuan kebijakan yang demikian hebatnya itu.

Klimaks dari berbagai protes dan kecaman yang berkecamuk terjadi ketika sebuah lembaga berbasis gerakan sosial, KPCDI (Komunitas Pasien Cuci Darah Indonesia), mengajukan pengujian materi (judicial review) terhadap Perpres Jaminan Kesehatan Perubahan Pertama tersebut ke Mahkamah Agung. KPCDI menilai bahwa kenaikan iuran yang di atur di dalam Perpres itu tidaklah logis, tidak manusiawi, dan tidak bersesuaian dengan Undang Undang Nomor 40 tahun 2004 tentang Sistem Jaminan Sosial Nasional dan Undang Undang Nomor 24 Tahun 2011 tentang Badan

\footnotetext{
11 Peraturan Presiden Nomor 28 Tahun 2016

12 Alinea ke-2 UUD NRI Tahun 1945
}

Penyelenggara Jaminan Sosial. Melalui Putusan No. 7 P/HUM/2020 bertanggal 31 Maret 2020, Mahkamah Agung ${ }^{13}$ akhirnya menyatakan bahwa Pasal 34 ayat (1) dan (2) Perpres No. 75 Tahun 2019 tentang Perubahan Atas Perpres No. 82 Tahun 2018 tentang Jaminan Kesehatan dibatalkan. Artinya, ketentuan yang terdapat di dalam pasal tersebut tidak lagi mempunyai ketentuan hukum yang mengikat. Berdasarkan keterangan dari Mahkamah Agung, pasal tersebut bertentangan dengan segelintir ketentuan di dalam beberapa peraturan perundang-undangan,

Ketentuan mengenai kenaikan tarif iuran BPJS Kesehatan yang termuat di dalam Pasal 34 ayat (1) dan (2) Perpres Jaminan Kesehatan Perubahan Pertama tersebut dinyatakan invalid dan iuran BPJS kembali ke tarif semula sebagaimana yang diatur di dalam Perpres No. 82 Tahun 2018 tentang Jaminan Kesehatan. Sebagai informasi, mekanisme pengujian materi yang dijalankan oleh Mahkamah Agung terhadap ketentuan tersebut sejatinya adalah salah satu bentuk kontrol norma hukum. Mekanisme tersebut dilakukan untuk menjaga kaidah-kaidah konstitusi yang termuat di dalam Undang-Undang dan peraturan perundangundangan konstitusional, agar tidak simpangi oleh dan dalam bentuk apapun Perpres Jaminan Kesehatan Perubahan Pertama dapat dikatakan sebagai regulasi hukum yang yang bersifat umum dan abstrak (general and abstract form). I

Implementasi dalam kehidupan rakyat Indonesia secara menyeluruh. Sehingga, apabila terdapat ketentuan di dalamnya yang tidak bersesuaian dengan kaidah-kaidah konstitusi, maka tidak ada cara lain untuk mengadili ketentuan hukum itu selain melalui mekanisme judicial review Hanya saja, pengujian materi oleh Mahkamah Agung terhadap Perpres No. 75 Tahun 2019 tersebut dilakukan secara tertutup Seperti yang dinyatakan sebelumnya, Perpres tentang Jaminan Kesehatan Perubahan Pertama merupakan regulasi hukum yang terimplementasi dalam kehidupan rakyat Indonesia secara menyeluruh. Rakyat

\footnotetext{
13 Putusan No. 7 P/HUM/2020 bertanggal 31 Maret 2020, Mahkamah Agung
} 
Indonesialah yang menjadi "sasaran" dari Perpres tersebut. Dengan demikian, rakyat Indonesia memiliki hak untuk mengetahui secara pasti proses pengadilan yang dilakukan oleh Mahkamah Agung kala memeriksa, mengadili, dan memutuskan bagaimana keberlakuan dari regulasi yang kelak akan mereka taati. Bukan pada tempatnya keterbukaan dari sebuah organisasi negara terhadap warga negaranya sendiri dapat diingkari. Penulis memiliki pandangan bahwa diperlukan adanya transparansi dari pihak Mahkamah Agung itu sendiri, transparansi dalam menggelar persidangan pengujian materi terhadap Perpres tentang Jaminan Kesehatan Perubahan Pertama tersebut. Hal ini didasari oleh beberapa hal, yang mana akan penulis jabarkan secara ringkas sebagai berikut.

Mekanisme keterbukaan dalam persidangan pengujian materi merupakan bentuk pemenuhan terhadap dua asas hukum, yaitu audi alteram et partem dan erga omnes. Asas yang pertama berlaku dalam proses mencari kebenaran, baik kebenaran formil maupun kebenaran materil yang harus mendengarkan dalil dari kedua belah pihak. Dalam memutus suatu perkara, dibutuhkan adanya tindakan yang mencari, menggali, mengumpulkan, membandingkan, menganalisis lalu pada akhirnya mengambil kesimpulkan berdasarkan bukti-bukti yang dihadirkan oleh para pihak tersebut. Kiranya, asas ini menjadi jaminan objektifitas majelis hakim dalam mengadili perkara yang ada. Asas yang kedua mengandung makna bahwa setiap putusan pengadilan bersifat final dan memiliki kekuatan yang mengikat. Putusan pengadilan berlaku tidak hanya bagi para pihak yang bersengketa, melainkan bagi semua pihak secara keseluruhan. Ini semakin memperkuat pernyataan bahwa putusan dari Mahkamah Agung terhadap Perpres tentang Jaminan Kesehatan Perubahan Pertama tersebut haruslah melalui suatu mekanisme yang transparan terhadap publik, sebab putusan itu pada akhirnya akan berlaku bagi publik itu sendiri.

Pada 5 Mei 2020, Presiden secara resmi menandatangani Perpres No. 64 Tahun $2020^{14}$ tentang Perubahan Kedua Atas Peraturan Presiden Nomor 82 Tahun 2018 tentang

14 Perpres No. 64 Tahun 2020
Jaminan Kesehatan. Sama halnya dengan peraturan sebelumnya, fokus utama yang menimbulkan polemik dari Perpres Jaminan Kesehatan Perubahan Kedua ini ialah mengenai kenaikan tarif Peserta Mandiri yang terbagi menjadi tiga klaster; Rp42 ribu dari Rp25,5 ribu untuk kelas III, Rp100ribu dari Rp51 ribu untuk kelas II, dan Rp150 ribu dari Rp80 ribu untuk kelas I, serta ditambah dengan adanya mekanisme subsidi untuk peserta dalam kategori Kelas III. Kita mengetahui bahwasanya Mahkamah Agung telah menetapkan ketentuan mengenai tarif kenaikan iuran BPJS Kesehatan yang diatur di dalam Perpres No. 75 Tahun $2019^{15}$ (perubahan pertama) tidak lagi berkekuatan hukum tetap.

Sebagaimana yang dinyatakan oleh Mahkamah Agung dalam putusannya, ketentuan terkait kenaikan tarif iuran di dalam Perpres tersebut menyalahi beberapa peraturan perundang-undangan dan tidak bersesuaian dengan esensi dari cita-cita bangsa untuk mewujudkan kepastian perlindungan dan kesejahteraan sosial bagi seluruh rakyat Indonesia. Akan tetapi, apa yang terdapat di dalam teori ternyata berbeda dengan praktiknya di lapangan, dan inilah masalahnya. Pemerintah terkesan tidak mengindahkan putusan yang telah dikeluarkan majelis hakim dalam judicial review terhadap Pasal 34 Perpres No. 75 Tahun 2019 tersebut di atas. Padahal, telah jelas bahwasanya pasal tersebut dinyatakan tidak lagi berkekuatan hukum tetap. Hal ini diatur di dalam Pasal 31 ayat (4) UndangUndang Nomor 5 Tahun 2004 tentang Perubahan Atas Undang-Undang Nomor 14 Tahun 1985 tentang Mahkamah Agung, yang berbunyi sebagai berikut: "Peraturan perundang-undangan yang dinyatakan tidak sah sebagaimana dimaksud pada ayat (3) tidak mempunyai kekuatan hukum mengikat."

Upaya pemerintah yang mengesampingkan putusan dari Mahkamah Agung tersebut merefleksikan sikap indisipliner yang dikhawatirkan mencederai budaya hukum di tengah-tengah masyarakat. Apabila masyarakat mengetahui bahwasanya pemerintah tidak mengindahkan apa yang telah ditetapkan, maka tidak menutup kemungkinan mereka akan cenderung melakukan hal yang sama, atau dalam hal ini, tidak mematuhi norma hukum

15 Perpres No. 75 Tahun 2019 
yang berlaku. Ini diperparah dengan adanya refraksi kala menuju pembentukan Perpres No. 64 Tahun 2020 (perubahan kedua) tersebut. Disebabkan BPJS Kesehatan terus mengalami defisit keuangan, pada akhirnya Kementerian Keuangan RI meminta Badan Pengawasan Keuangan dan Pembangunan (BPKP) untuk melakukan pengauditan terhadap BPJS Kesehatan.

Hal itu dilakukan di samping untuk mengetahui penyebab pasti dari problem defisit keuangan yang menahun, juga untuk mencari solusi bagaimana problem tersebut dapat diselesaikan sehingga mekanisme pengelolaan BPJS Kesehatan dapat berjalan lancar dan dapat beroperasi sebagaimana mestinya. Namun, Kementerian Keuangan beranggapan bahwa dokumen hasil pengauditan dari BPKP tersebut tidak perlu untuk dipublikasikan secara luas. Mereka menilai bahwa dokumen itu merupakan informasi yang dikecualikan untuk publik.

Ada dua alasan mengapa Kementerian Keuangan bersikap demikian. Pertama, publikasi hasil audit tersebut dianggap dapat merugikan ketahanan ekonomi nasional. Kedua, hasil audit itu dinilai sebagai memorandum yang sifatnya dirahasiakan. Kedua alasan ini mengacu pada Undang-Undang Nomor 14 Tahun 2008 tentang Keterbukaan Informasi Publik (UU KIP). ${ }^{16}$ Jelas sekali pemerintah tidak bersifat transparan. Jika memang benar dokumen hasil audit BPJS Kesehatan merupakan bentuk informasi yang dikecualikan dari publik, maka sepatutnya ada parameter yang jelas dari pemerintah untuk setiap orang mengetahui bagaimana dokumen hasil audit tersebut dapat merugikan ketahanan ekonomi nasional. Kemudian, frasa "ketahanan ekonomi nasional" itu sendiri tidaklah jelas dan tidak pula dijelaskan oleh pihak yang bersangkutan. Kemudian, merujuk pada Pasal 2 ayat (4) UU KIP, dijelaskan mengenai suatu mekanisme berupa uji konsekuensi terhadap informasi publik yang dikecualikan dan bersifat rahasia.

Kejelasan dari Kementerian Keuangan selaku pihak yang bertanggung jawab terhadap dokumen hasil audit BPJS Kesehatan akan pelaksanaan dari mekanisme uji konsekuensi tersebut. Seharusnya, sebagai salah satu

16 Undang-Undang Nomor 14 Tahun 2008 tentang Keterbukaan Informasi Publik (UU KIP). organisasi negara, Kementerian Keuangan dapat bersikap gamblang dan berpihak kepada rakyat. Dalam hal ini, konteksnya adalah pro akan keterbukaan informasi yang menyangkut kemaslahatan publik, karena publik berhak tahu akan apa yang mereka hadapi ke depan dan apa yang akan "hadir" di tengah-tengah mereka. Terlebih, sikap organisasi negara yang terbuka itu sendiri merupakan indikasi dari adanya tata kelola pemerintahan yang baik (Good Governance) dalam penyelenggaraan negara. Sampai di sini, kita telah melihat bagaimana teatrikal dari lembaga-lembaga negara dalam jalannya isu kenaikan tarif iuran BPJS Kesehatan tersebut. Kita melihat eksistensi putusan inkracht dari Mahkamah Agung, ditambah dengan adanya kaidah hukum yang disimpangi dalam peraturan perundangundangan terkait, disertai anomali terhadap nilai-nilai sosial yang berlaku di masyarakat, serta diperparah dengan organisasi negara yang seolah tak terjangkau oleh publik. Namun, pemerintah tampaknya tidak peduli dengan semua itu. Pemerintah seolah menyangkal bahwa regulasi hukum yang mereka ciptakan cacat dari sudut pandang yuridis pun moralitas.

Pemerintah tidak menjalankan peran mereka sebagai personifikasi negara yang menjunjung tinggi kaidah-kaidah konstitusi yang telah ada sejak dulu. Jalan Tengah bagi Semuanya Berbagai pemaparan di atas agaknya telah menjawab pertanyaan kita pada awal kajian ini. Mengapa timbul protes juga kritik dari masyarakat akan kebijakan pemerintah mengenai kenaikan tarif iuran BPJS Kesehatan? Secara garis besar, alasan utamanya ialah kombinasi dari ketentuan hukum yang menyimpangi kaidah-kaidah di dalam peraturan perundang-undangan dan sikap dari berbagai pihak terkait yang cenderung tertutup serta tidak menunjukkan keberpihakan kepada publik. Protes dan kritik yang timbul menjadi bukti bahwa skema pemerintah yang menaikkan tarif iuran JKN BPJS Kesehatan tersebut tidaklah tepat.

Dibutuhkan upaya nyata yang mampu mengalkulasikan kemungkinan terbaik agar tercipta sebuah jalan tengah yang di samping mengatasi permasalahan defisit keuangan BPJS Kesehatan juga mengimbangi taraf kehidupan masyarakat secara keseluruhan, terlebih dalam masa pandemi COVID-19 seperti sekarang ini. 
Dalam hal ini, satu-satunya solusi yang bisa Penulis kemukakan bagi pemerintah dan pihakpihak terkait ialah dengan mencari akar primordial dari problem yang ada. Perlu adanya observasi mendalam dan tinjauan yang berlanjut untuk mendapatkan kepastian akan perihal yang melatarbelakangi defisit keuangan menahun yang dialami oleh BPJS Kesehatan tersebut.

Tidak menutup kemungkinan akan adanya kausa-kausa lain yang menyebabkan problem itu terjadi, dan karenanya akan tercipta suatu jalan tengah yang menguntungkan bagi kita semua. Apabila pemerintah bersungguhsungguh dalam mewujudkan cita-cita bangsa Indonesia untuk membangun kepastian perlindungan dan kesejahteraan sosial bagi seluruh warga negara, melalui program JKN BPJS Kesehatan, maka upaya yang wajib ditempuh tak lain adalah upaya yang bertumpu pada kemudahan masyarakat untuk berkontribusi agar program JKN BPJS Kesehatan tersebut berjalan sebagaimana mestinya. Sehingga pada akhirnya, cita-cita bangsa yang telah diamanatkan di dalam konstitusi tertinggi negara dapat benar-benar terwujud. Sebagai penutup, Penulis mengutip satu adagium yang dikemukakan oleh Cicero. Salus Populi Suprema Lex Esto. "Keselamatan Rakyat Merupakan Hukum Tertinggi".

\section{PENUTUP}

\section{A. Kesimpulan}

1. Dari hasil penelitian yang diperoleh, maka dapat disipulkan bahwa persepsi keluarga pasien pengguna layanan BPJS kesehatan terhadap pelayanan di Rumah Sakit Islam Kendal baik yang dilihat dari segi prosedur pelayanan admisitrasi, kualitas pelayanan rawat inap, maupun sarana dan prasarana termasuk dalam kategori baik. Hal itu bisa dilihat dari besarnya skor persepsi baik terhadap pelayanan Rumah sakit Islam Kendal, yaitu sebanyak $63,6 \%$, Yang artinya sebagian besar keluarga pasien pengguna layanan kesehatan BPJS mempunyai persepsi yang baik terhadap kualitas pelayanan BPJS di Rumah Sakit Islam Kendal.

2. Dalam hal ini, satu-satunya solusi yang bisa Penulis kemukakan bagi pemerintah dan pihak-pihak terkait ialah dengan mencari akar primordial dari problem yang ada. Perlu adanya observasi mendalam dan tinjauan yang berlanjut untuk mendapatkan kepastian akan perihal yang melatarbelakangi defisit keuangan menahun yang dialami oleh BPJS Kesehatan tersebut. Sebab tidak menutup kemungkinan akan adanya kausa-kausa lain yang menyebabkan problem itu terjadi, dan karenanya akan tercipta suatu jalan tengah yang menguntungkan bagi kita semua

\section{B. Saran}

1. Bagi pihak Rumah Sakit untuk bisa mempertahankan atau bahkan lebih meningkatkan kualitas pelayanan, baik dari segi pelayanan administrasi, pelayanan medis baik rawat jalan maupun rawat inap, serta kelengkapan sarana dan prasarana. Disamping itu hendaknya memperbanyak pelatihan-pelatihan dan pendidikan tentang pelayanan bermutu mulai dari pengetahuan maupun ketrampilan sehari-hari.

2. Apabila pemerintah bersungguh-sungguh dalam mewujudkan cita-cita bangsa Indonesia untuk membangun kepastian perlindungan dan kesejahteraan sosial bagi seluruh warga negara, melalui program JKN BPJS Kesehatan, maka upaya yang wajib ditempuh tak lain adalah upaya Kesehatan tersebut berjalan sebagaimana mestinya. Sehingga pada akhirnya, cita-cita bangsa yang telah diamanatkan di dalam konstitusi tertinggi negara dapat benarbenar terwujud.

\section{DAFTAR PUSTAKA}

Ady Thea DA, "Inilah 12 Ketentuan dalam Perpres Jaminan Kesehatan yang Perlu Dicermati", https://www.hukumonline.com/ber ita/baca/It5bab443c5f973/inilah-12-ketentuandalam-perpres-jaminan-kesehatan-yang-perludicermati/, diakses pada 1 Juli 2020.

Syofyan Hadi, Tomy Michael, "Principles of Defense (Rechtmatigheid) in Decision Standing 
of State Administration", Jurnal Cita Hukum, Vol. 5, No. 2, 2017, hlm. 385.

Hendra Friana, "Jokowi Teken Perpres 75/2019, Iuran BPJS Kesehatan Resmi Naik", https://tirto.id/iokowi-teken-perpres752019-iuran-bpjs-kesehatan-resmi-naik-ekNS, diakses pada 1 Juli 2020.

Secara spesifik, ketentuan mengenai mekanisme baru terkait tarif iuran JKN BPJS Kesehatan yang berlaku per 1 Januari 2020 tersebut dapat dilihat pada beberapa pasal, seperti pada Pasal 29, 30, 32, 33, dan Pasal 103A.

Agatha Olivia Victoria, "Sri Mulyani Beberkan Empat Penyebab Defisit BPJS Keuangan", https://katadata.co.id/berita/2019/ 08/21/sri-mulyani-beberkan-empat-penyebabdefisit-bpis-keuangan, diakses pada 1 Juli 2020. Ahda Bayhaqi, "Rapat Gabungan, DPR Ngotot Tolak Kenaikan luran BPJS Kesehatan", https://www.merdeka.com/politik /rapat-gabungan-dpr-ngotot-tolak-kenaikaniuran-bpjs-kesehatan.html, diakses pada 2 Juli 2020.

KPCDI, "Dinilai Diskriminatif, KPCDI Gugat Perpres 75/2019 ke MA", https://kpcdi.org/2019/12/06/dinilaidiskriminatif-kpcdi-gugat-perpres-75-2019-kema/, dikases pada 2 Juli 2020.

Mohammad Mahrus Ali, "Konstitusionalitas dan Legalitas Norma dalam Pengujian UndangUndang Terhadap Undang-Undang Dasar 1945", Jurnal Konstitusi, Vol. 12, No. 1, 2015, hIm. 1.

Mochamad Januar Rizki, "Penjelasan Hukum Soal Polemik luran BPJS Kesehatan Pasca Putusan

MA", https://www.hukumonline.com/berita/ba ca/It5e8c04de0d65a/penjelasan-hukum-soalpolemik-iuran-bpjs-kesehatan-pasca-putusanma/, diakses pada 3 Juli 2020.

D. Y. Witanto, Hukum Acara Praperadilan dalam Teori dan Praktik, Depok: Imaji Cipta Karya, 2019, hlm. 16.

Mesraini, "Interkoneksi Mahkamah Konstitusi dengan Mahkamah Agung; Studi Implementasi Putusan tentang Nasab Anak", Jurnal Sosial \& Budaya Syar-i, Volume 4, Nomor 1, 2017, hlm. 2.

Berdasarkan pegangan bagi perilaku hakim yang telah diadopsi oleh PBB melalui Dewan
Ekonomi dan Sosial dalam Resolusi 2006/23 dari Bangalore Principles of Judicial Conduct.

Wibi Pangestu Pratama, "Ini Alasan Sri Mulyani Tak Buka Hasil Audit BPJS Kesehatan", https://finansial.bisnis.com/read/2 0200622/215/1256121/ini-alasan-sri-mulyanitak-buka-hasil-audit-bpjs-kesehatan-saatdiminta-icw, diakses pada 3 Juli 2020.

World Bank, Governance: The World Bank's Experience, A World Bank Publication, 1994, hlm. vii. 